\title{
OBIEKTYWNY CHARAKTER DOBRA W SZKOLE LWOWSKO-WARSZAWSKIEJ: K. TWARDOWSKI, W. TATARKIEWICZ, T. CZEŻOWSKI
}

Przekonanie o bezwzględnym charakterze prawdy oraz absolutyzm logiczny są charakterystycznymi rysami formacji intelektualnej zwanej Szkołą Lwowsko-Warszawską ${ }^{1}$. Miało to swoje odzwierciedlenie w ich podejściu do zagadnień aksjologicznych. W niniejszym artykule chcę się przyjrzeć argumentacji, jaką trzej przedstawiciele tej szkoły, to jest Kazimierz Twardowski, Władysław Tatarkiewicz oraz Tadeusz Czeżowski, wysuwali za tezą o bezwzględnym charakterze dobra.

Argumenty te można podzielić na dwie ogólne grupy. Pierwsza ma charakter negatywny i sprowadza się do wykazania błędów w argumentacji za subiektywizmem i relatywizmem jako dwoma stanowiskami występującymi łącznie i podważającymi tezę o bezwzględnym charakterze dobra. Druga grupa ma charakter pozytywny i związana jest z podejmowanym przez przedstawicieli Szkoły wysiłkiem takiego skonstruowania koncepcji aksjologicznej oraz etycznej, która wychodząc od tezy o bezwzględnym charakterze dobra, będzie poprawna i uniknie błędów oraz zarzutów formułowa- 
nych przez myślicieli stojących na gruncie relatywizmu i subiektywizmu. W niniejszym artykule zajmę się tylko pierwszą grupą argumentów, z konieczności zostawiając tę drugą kwestię na inną okazję.

Przez obiektywny charakter dobra rozumiem tezę, która głosi, że dobro jest niezależne od podmiotu oraz jest niezmienne. Jest ono synonimem wartości najwyższej oraz w ogóle aktów wartościowania. Podmiot nie wytwarza wartości, lecz odkrywa je. Określenie to ma charakter ogólny i wstępny.

\section{Kazimierz Twardowski}

Argumentację skierowaną przeciwko relatywizmowi i subiektywizmowi w filozofii Twardowski przedstawił przede wszystkim w rozprawie $O$ tak zwanych prawdach względnych ${ }^{2}$. W pracy tej analizy podważające prawomocność argumentacji relatywizmu i subiektywizmu w etyce potraktowane są równorzędnie do tego samego typu argumentacji w epistemologii. Skuteczne odrzucenie argumentacji sceptycznej $w$ epistemologii niesie za sobą pozytywne rozstrzygnięcia w etyce oraz aksjologii ${ }^{3}$.

Twardowski zakładał, że relatywizm i absolutyzm wyznaczają pole możliwej spekulacji w filozofii, ponieważ są to stanowiska sprzeczne w sensie logicznym. Dla wykazania słuszności tezy obiektywizmu należy zbić argumenty przeciwne. Jak ujął to nieco później Tatarkiewicz: „Innego dowodu prawdziwości obiektywizmu niż dowód fałszywości subiektywizmu nie potrzeba. Dowodząc bowiem fałszywości subiektywizmu, dowodzę, że dobro i zło są niezależne od podmiotu, a przez to samo dowodzę prawdziwości obiektywizmu"4.

Prawdy bezwzględne, jego zdaniem, to sądy prawdziwe bezwarunkowo, bez żadnych zastrzeżeń i okoliczności, zawsze i wszędzie. To samo odnosi się do zasad etycznych ${ }^{5}$. W swojej analizie Twardowski wskazuje przede wszystkim na błędy logiczne zawarte $\mathrm{w}$ argumentacji za relatywizmem.

Względność norm można uzasadniać, powołując się na wyjątki od ogólnych zasad etycznych. Twardowski wskazuje, że w takim wypadku norma

$2 \mathrm{~K}$. Twardowski, O tak zwanych prawdach względnych, [w:] idem, Wybrane pisma filozoficzne, Warszawa 1965, s. 314-336.

${ }^{3}$ R. Jadczak, Człowiek szukajacy etyki. Filozofia moralna Kazimierza Twardowskiego, Torun 1993, s. $92-106$.

${ }^{4}$ W. Tatarkiewicz, O bezwzględności dobra, [w:] idem, Pisma z etyki i teorii szczęścia, Wrocław - Warszawa - Kraków 1992, s. 45.

${ }^{5}$ K. Twardowski, op. cit., s. 315 i 324 
ta od początku nie była ogólna, lecz szczegółowa. Wobec tego należy ją przeformułować tak, by ująć ją bardziej precyzyjnie. Norma w takiej formie jest bezwzględna.

Drugi typ argumentacji relatywistów opiera się na obserwacji, że pewne normy obowiązywały kiedyś, a teraz nie, i odwrotnie. Dowodzić to ma względności kulturowej i historycznej norm etycznych. Jednakże, zdaniem Twardowskiego, argumentację tę można zbić, pytając się o to, czy normy obowiązywały słusznie, czy też niesłusznie? Pytanie to zaś zakłada dwa rozstrzygnięcia. Jeśli były słuszne, to znaczy, że miały charakter bezwzględny, a to, że nie obowiązują teraz, oznacza tylko, że nie zachodzą warunki, w których można by je przywołać. Jeżeli zaś odpowiedź byłaby negatywna, to znaczy, że zasady te należało odrzucić jako mylne. Obie odpowiedzi dowodzą zaś bezwzględnego charteru norm etycznych.

Trzeci argument relatywistów wychodzi od obserwacji dopuszczania wyjątków od ogólnych zasad etycznych. Dowodzić to ma względności zasad etycznych. Wniosek taki, zdaniem Twardowskiego, jest niepoprawny. Argument relatywistów wskazuje, że sformułowanie ogólnych i niedopuszczających wyjątków norm etycznych może być zadaniem niewykonalnym, a zatem zadaniem etyki jest tworzenie i dowodzenie słuszności zasad szczegółowych. Zasady te, jeśli są słuszne, to są bezwzględnie słuszne.

Ostatni argument relatywizmu przywołany przez Twardowskiego opiera się na obserwacji względności kulturowo-historycznej pojęć dobra i zła. Sens terminu "dobro" zmienia się historycznie i kulturowo, dlatego obecnie może zawierać zakresowo coś, co kiedyś wchodziło w zakres "zła”, i odwrotnie. Jednakże odmienne znaczenia historyczne pojęć "dobra” i „zła” są nieporównywalne. Ponieważ historyczne znaczenia tych słów są uwikłane $\mathrm{w}$ odmienne konteksty społeczno-kulturowe, znaczenia te nie są w pełni na siebie przekładalne. Nadto dwa pojęcia dobra (lub zła), wzięte z różnych czasów, niekoniecznie muszą być w relacji sprzeczności logicznej. Może to być przeciwieństwo, krzyżowanie się zakresów, nadrzędność czy podrzędność. Względność znaczeń nie dowodzi natomiast względności dobra i zła ${ }^{6}$.

\section{Władysław Tatarkiewicz}

Praca habilitacyjna Władysława Tatarkiewicza O bezwzględności dobra poświęcona jest między innymi gruntownej analizie argumentacji relatywizmu i subiektywizmu wymierzonej przeciw obiektywnemu charakte-

${ }^{6}$ Ibidem, s. 324-326. 
rowi dobra. Po jej przeprowadzeniu, autor przedstawia własne stanowisko, wychodząc od tezy o bezwzględnym charakterze dobra.

Punktem wyjścia dociekań autora jest założenie o sprzeczności logicznej zachodzącej między relatywizmem i absolutyzmem. Punkt ten pozwala mu twierdzić, że dowodem prawdziwości absolutyzmu jest oddalenie krytyki płynącej ze strony relatywizmu. Relatywizm to pogląd, który uznaje dobro oraz zło zarówno w etyce, jak i aksjologii, za cechy względne. Teza ta ma dwa sformułowania. Pierwsze, że d obro jest względne w odniesieniu do podmiotu, który o nim orzeka. Drugie, że dobro jest względne z uwagi na cel, któremu może sł u ż y ć. W obu przypadkach można dojść do podobnej tezy: „W pierwszej postaci relatywizm etyczny twierdzi, że jeśli $P$ jest dobrem, to jest nim dla kogoś; w drugiej zaś twierdzi, że jeśli jest dobrem, to do czegoś"7.

Przez subiektywizm rozumie Tatarkiewicz teorię, która uważa cechę będącą podstawą podziału obiektów na klasy za subiektywną, to jest zależną od jakiegoś podmiotu. W efekcie, subiektywizm logiczny to teoria głosząca, że prawdziwość i fałszywość ma charakter subiektywny, zaś subiektywizm etyczny miałby oznaczać analogiczną teorię w odniesieniu do wartości dobra i zła. Dobro i zło, jako cechy przedmiotów, są zależne od podmiotu. Przedmiot sam w sobie nie jest ani dobry, ani zły ${ }^{8}$.

Subiektywizm i relatywizm są nie są powiązane logicznie, lecz psychologicznie, ponieważ wypływają z podobnego źródła i na ogół są wyznawane łącznie. Zarówno cecha względna może być obiektywna, jak i cecha subiektywna może być bezwzględna. Prawdziwość czy fałszywość jednej z tych teorii nie oznacza prawdziwości czy fałszywości drugiej. Obie teorie na terenie etyki mają wspólne konsekwencje. Jeśli dobro jest cechą względną, to przedmiot dobry może przestać nim być. Podobnie rzecz się przedstawia, jeśli dobro jest cechą subiektywną - przedmiot może przestać nim być. Przedmiot wciąż jest ten sam, jednak wartość swoją raz traci, a raz ją posiada, co prowadzi do tezy o niestałości dobra, i - analogicznie - zła, jako wartości. Tak więc konsekwencją obu koncepcji jest niestałość dobra.

Relatywizm jest teorią, która dotyczy własności rzeczy dostępnych bezpośredniemu doświadczeniu. Subiektywizm zaś dotyczy czegoś, co jest dane pośrednio za pomocą rozumowania. $Z$ tego powodu relatywizm nie potrzebuje dowodzenia i rozumowania, za to wymaga tego subiektywizm. Analogicznie rzecz dotyczy bezwzględności i obiektywności - ten pierwszy pogląd nie potrzebuje dowodu, ten drugi - tak. Dowodu więc potrzebują subiektywizm i obiektywizm.

${ }^{7}$ W. Tatarkiewicz, op. cit., s. 19.

8 Ibidem, s. 24-25. 
Zwolennicy subiektywizmu odwoływali się do czterech zasadniczych typów argumentacji. Pierwszym argumentem za subiektywizmem ma być fakt niezgodności sądów etycznych: dwie różne osoby wydają przeciwne twierdzenia na temat dobra i zła. Nie dowodzi to jednak słuszności subiektywizmu, ponieważ interpretacja subiektywistyczna jest jedną z kilku interpretacji tego faktu.

Drugi argument odwołuje się do relatywizmu: wartości są subiektywne, ponieważ są względne w stosunku do osób wygłaszających sądy wartościujące. Siła tej argumentacji zależy od prawdziwości relatywizmu, którą można zakwestionować. Jednakże nawet jeśli uznać prawdziwość przesłanki, to nie wynika z niej teza subiektywizmu. Cecha względna nie musi być subiektywna: na przykład to, czy dany obiekt jest daleko czy blisko od innego, jest cechą względną, ale nie jest cechą subiektywną. W argumencie tym można więc dopatrzeć się dwóch zasadniczych błędów w rozumowaniu: materialnego (fałszywość relatywizmu) i formalnego (brak związku logicznego między przesłanką a wnioskiem).

W trzecim argumencie wskazuje się na związek między wartościowaniem a emocjami. $W$ jego przesłankach uznaje się, że uczucie ma $\mathrm{w}$ pełni swoje źródło w podmiocie, a także przyjmuje się istnienie związku między wartościowaniem a uczuciami. W efekcie otrzymujemy poprawne formalnie rozumowanie sylogistyczne w postaci: (1) wszystko, co jest rzeczą uczucia, jest subiektywne; (2) wartości są rzeczą uczucia; z czego wynika wniosek: (3) wartości są subiektywne. Podważając to rozumowanie, Tatarkiewicz wskazuje na błędy zawarte w jego przesłankach. Nie jest pewne, czy wartości są całkowicie rzeczą uczucia, potrzebny byłby tu dodatkowy dowód. Czy ocena jakiegoś czynu jest całkowicie rzeczą uczucia, jest powiązana z uczuciem, a może nie ma takiego związku? - nie jest przesądzona pewność pierwszego składnika tej alternatywy. Dowodu również wymagałaby teza, że wszystko, co jest rzeczą uczucia, jest subiektywne. Związek taki nie ma charakteru koniecznego. Dlatego rozumowanie to nie jest dostatecznym argumentem dla poparcia tezy subiektywizmu.

Czwarty argument za subiektywizmem wskazuje na różne wartościowania tego samego przedmiotu przez ten sam podmiot $\mathrm{w}$ różnym czasie. To, co wcześniej było wartościowe dla kogoś, dziś już takim nie jest, i odwrotnie. Ponieważ przedmiot wartościowania się nie zmienił, stąd wniosek, że zmiana wartościowania zależna jest od zmiany w podmiocie, co uzasadnia tezę subiektywizmu. Wniosek ten można podważyć. Jeśli ktoś korzystał z czegoś w dzieciństwie ze względu na przyjemność czy korzyść, to znaczy, że przedmiot ten posiadał pewną wartość. Wartości tej nie utracił, chociaż ktoś, jako osoba dorosła, już z niego nie korzysta. Osoba ta o wartości tej 
rzeczy może zapomnieć lub błędnie jej odmawiać. Dlatego można konkludować, że nie tyle przedmiot utracił wartość ze względu na zmianę w podmiocie, co przedmiot wciąż posiada tę wartość, jednakże nie jest ona wyraźna dla podmiotu ani podmiot $\mathrm{z}$ wartości tej nie korzysta aktualnie ${ }^{9}$.

Subiektywizm etyczny może też być konsekwencją teorii bardziej ogólnych. Może być wyprowadzany jako konsekwencja subiektywizmu powszechnego. Ten argument nie jest poprawny tak długo, jak długo teza subiektywizmu ogólnego nie jest dowiedziona. Podobnie może być on traktowany jako konsekwencja relatywizmu powszechnego. Podobnie jak wyżej, teza ta potrzebuje dowodu, ale nawet jeśli relatywizm byłby prawdziwy, nie wynikałby z niego subiektywizm. Dalej, może być on konsekwencją sensualizmu. W tym wypadku wartość dodatnia byłaby tożsama z przyjemnością, a ujemna z przykrością. Jednakże ze względu na to, że tożsamość między przyjemnością a wartością dodatnią nie zawsze zachodzi, sensualizm nie jest wsparciem dla subiektywizmu. Wreszcie subiektywizm może być konsekwencją tezy o powszechnej zmienności rzeczy, czyli mutabilizmu. Jednak nie ma związku logicznego między obydwoma poglądami: mutabilizm głosi, że własności rzeczy nie są trwałe, a subiektywizm, że nie są obiektywne. Oba poglądy dotyczą więc czegoś innego.

W konkluzji swej analizy Tatarkiewicz stwierdza, że subiektywizm etyczny jest nieuzasadniony. Nie płynie z tego jednak wniosek, że tezy subiektywizmu etycznego są fałszywe. Na potwierdzenie fałszywości subiektywizmu autor przytacza dodatkowy dowód, którego, ze względu na jego obszerność, nie będę tu przytaczał ${ }^{10}$.

\section{Tadeusz Czeżowski}

Już od początku działalności naukowej zainteresowania Tadeusza Czeżowskiego kierowały się w stronę etyki oraz aksjologii. Podobnie jak Twardowski oraz Tatarkiewicz, stał Czeżowski na stanowisku obiektywnego charakteru dobra. Czeżowski podzielał argumenty wymierzone przeciwko relatywizmowi oraz subiektywizmowi formułowane przez Twardowskiego oraz Tatarkiewicza. $W$ jego interpretacji oba stanowiska związane są z błędem psychologizmu, który w swoim czasie ciążył również nad badaniami logicznymi. Przezwyciężenie psychologizmu, między inny-

\footnotetext{
${ }^{9}$ Ibidem, s. 39-41.

${ }^{10}$ Ibidem, s. 41-44.
} 
mi dzięki badaniom Twardowskiego, było istotnym krokiem na drodze do rozwoju logiki współczesnej.

Błąd subiektywizmu ma swoje źródło w nieodróżnianiu dwóch semantycznych funkcji języka, to jest wyrażania i znaczenia. Przeżycia moralne można badać od dwóch stron: koncentrując się na samym fakcie doznawania, co ma swój wyraz między innymi w języku (i to jest zadanie psychologii), oraz badając przedmioty intencjonalne, o których orzeka się $\mathrm{w}$ wypowiedziach wyrażających przeżycia moralne. Przedmiotem etyki nie jest przeżycie moralne, lecz przedmioty intencjonalne, przez które rozumieć należy wartości etyczne, oceny i normy ${ }^{11}$.

Nie odróżniając dostatecznie dwóch funkcji języka, subiektywizm stoi na stanowisku, że wartość jest jedynie treścią doznania, a nie poznania. W efekcie subiektywiści uznają, że wartości są wyrażeniami, które nie wzbogacają opisu przedmiotu. Dlatego też są poznawczo puste $w$ tym sensie, że dają jedynie informacje o stanach emocjonalnych podmiotu, lecz nie o przedmiocie $^{12}$.

Czeżowski zarzuca takiemu ujęciu niedokładność analizy. Oceny wartości poznajemy za pośrednictwem uczuć, jednakże subiektywizm pomija fakt, że uczucia są zjawiskiem złożonym. To nie ocena jest wtórna wobec uczuć, lecz odwrotnie - uczucia i stany emocjonalne są wtórne wobec wartości. Dla poparcia swojego stanowiska Czeżowski przedstawia analizę przeżycia wartości. Zawiera ono cztery elementy: (1) przedstawienie, to jest mentalny obraz przedmiotu, sytuacji, zdarzenia itp.; (2) ocenę tego stanu rzeczy; (3) przeżycie uczucia przyjemności lub przykrości; (4) przedmiot uczucia. Kluczowy jest czwarty, pomijany przez subiektywizm, element: istnienie przedmiotu uczucia. Istnienie to jest niezależne od podmiotu, bowiem gdyby było zależne, podmiot mógłby dowolnie modelować swoje przeżywanie przykrości i przyjemności. Tak się jednak nie dzieje - przedmioty nieistniejące uczucia te wywołują co najwyżej w niewielkim stopniu. Uczucie przyjemności lub przykrości znika, gdy nie towarzyszy mu element egzystencjalny ${ }^{13}$.

Czeżowski zgadza się, że określenia wartościujące różnią się od określeń własności przedmiotów, to jest że nie dodają niczego do opisu własności

11 T. Czeżowski, Etyka a psychologia i logika, [w:] idem, Pisma z etyki i teorii szczęścia, Wrocław - Warszawa - Kraków - Gdańsk - Łódź 1989, s. 109.

12 T. Czeżowski, Czym są wartości (wprowadzenie do dyskusji), [w:] idem, Pisma z etyki, op. cit., s. 117.

13 Ibidem, s. 117-118. Szczegółową rekonstrukcję związku między uczuciem a wartościowaniem przedstawia D. Łukasiewicz w książce: Filozofia Tadeusza Czeżowskiego, Bydgoszcz 2002, s. 280-285. 
przedmiotu. Różnica ta nie świadczy o ich beztreściowości, lecz o tym, że ich charakter z logicznego punktu widzenia jest inny niż wyrażeń kategorialnych, takich jak „okrągły”, „barwny” itp. Orzeczenia kategorialne odnoszą się, ogólnie rzecz biorąc, do przeróżnych treści empirycznych, natomiast określenia ponadkategorialne - a wśród nich takie, jak np. „dobro" - nie są przedstawialne, lecz tworzą inną grupę wyrażeń modalnych. „Tak więc nieprzedstawialne określenia: istnienie lub prawdziwość, konieczność i możliwość, piękność, wartość moralna lub dobroć, nie są wprawdzie cechami przedmiotów, lecz przysługują im jako określenia stwierdzalne w zdaniach modalnych"14.

Czeżowski nie uważał, by obiektywność czy bezwzględność ocen była istotna dla teorii etycznej. Kluczowe dla niego było, aby „oceny były intersubiektywnie komunikowalne i sprawdzalne lub, mówiąc po prostu, by różni badacze mogli się ze sobą porozumieć co do tego, jak oceniają i czy oceniają zgodnie"15. Jednakże ujmując dobro jako jedno z transcendentaliów, dostarczył on kolejnego argumentu na rzecz tezy o bezwzględności dobra. Dodatkowo pogląd ten wzmacnia teza o tym, że oceny mogą być prawdziwe albo fałszywe i że tworzą one wiedzę, ponieważ odnoszą się one do swoistej empirii aksjologicznej. Sądzę, że teza o istnieniu takiego doświadczenia była podzielana przez trzech wspomnianych przeze mnie filozofów.

\section{Podsumowanie}

Przedstawione powyżej argumenty na rzecz obiektywnego charakteru dobra pochodzą od filozofów zaliczanych do tego samego środowiska filozoficznego. Mimo że akceptują oni wspólną tezę o obiektywnym i bezwzględnym (nierelatywnym) charakterze dobra, to dla wykazania jej słuszności posługują się innymi argumentami. Argumenty te uzupełniają się z dwóch względów - po pierwsze, z powodu podzielania przez wspomnianych filozofów tej samej tezy o bezwzględnym i obiektywnym charakterze dobra; po wtóre, ze względu na podobieństwo rozstrzygnięć metafilozoficznych, zgodnie z którymi poprawność logiczna jest jedną z pierwszych dyrektyw, jaką spełniać powinny rzetelne dociekania filozoficzne ${ }^{16}$.

Argumenty te dzieli ponad pięćdziesiąt lat, w trakcie których prowadzono intensywne analizy aksjologiczne, etyczne i metaetyczne. Argumenty

\footnotetext{
${ }^{14}$ T. Czeżowski, Czym sa wartości..., op. cit., s. 118.

15 T. Czeżowski, Etyka jako nauka empiryczna, [w:] idem, Pisma z etyki, op. cit., s. 102.

${ }^{16}$ J. Woleński, op. cit., s. 42-44.
} 
Twardowskiego przytoczyłem na podstawie jego prac z przełomu XIX i XX wieku. Wywody Tatarkiewicza pochodzą z jego rozprawy habilitacyjnej powstałej około dwadzieścia lat później, zaś analizy Czeżowskiego przedstawione są na podstawie jego prac powstałych po II wojnie światowej.

Argumentacja przedstawiona przez Twardowskiego ma w jego filozofii charakter wstępny w stosunku do mającej nastąpić po niej etyce o charakterze naukowym. Niestety, za życia filozof nie opublikował rozprawy o takim charakterze i została ona wydana długo po jego śmierci staraniem Ryszarda Jadczaka17. Praca ta ujawnia trudności, z jakimi mierzył się filozof w odnalezieniu kryterium etycznego, które miało być podstawą etyki o charakterze naukowym. O ile więc Twardowski potrafił w swoich analizach wykazywać błędy stanowiska, które było mu obce, czyli relatywizmu, o tyle też trudno było mu wypracować jakieś spójne stanowisko pozytywne. Rozwiązania takie można odnaleźć u jego uczniów, w tym Tatarkiewicza i Czeżowskiego. Być może wpływ ma na to podejście Twardowskiego, którego cechą charakterystyczną była niechęć do zbudowania wielkiego systemu filozoficznego, a podejmowane problemy analizował $\mathrm{z}$ różnych punktów widzenia. $\mathrm{W}$ każdym razie, zdawał on sobie sprawę z tego, że etyka naukowa musi wiązać dwa różne punkty widzenia - $z$ jednej strony musi posiadać charakter aprioryczny, przez co jej szczegółowe zasady są dedukowane $\mathrm{z}$ jednej zasady naczelnej, z drugiej strony musi ona uwzględniać konkretną praktykę życia społecznego i jej przeróżne uwarunkowania (społeczne, ekonomiczne, polityczne itp.), w których ludzie żyją. W tym kontekście kwestia prawdziwości zasad etycznych i sądów wartościujących traci na jasności, ponieważ by faktycznie móc stwierdzić prawdziwość jakiejś oceny, trzeba by posiadać wiedzę o wszystkich uwarunkowaniach, w których dana ocena jest podejmowana. Wydaje się to co najmniej trudne, jeśli nie niemożliwe ${ }^{18}$. Zdawał sobie $\mathrm{z}$ tego sprawę Tatarkiewicz, który z tego względu uznawał relatywizm słuszności postępowania i względność reguł, na jakich jest ono oparte.

$\mathrm{W}$ odniesieniu do podejmowanego tu zagadnienia, szczególną uwagę zwrócić należy na analizy Tatarkiewicza z jego rozprawy habilitacyjnej. Jeśli

${ }^{17}$ K. Twardowski, Etyka, Toruń 1994. Główny zarys tej rozprawy powstał prawdopodobnie pomiędzy 1898 a 1900 rokiem, czyli w podobnym czasie jak tekst rozprawy $O$ tak zwanych prawdach względnych. Prawdopodobnie służyła ona jako podstawa wykładów z etyki prowadzonych przez Twardowskiego. Swoje poglądy Twardowski prezentował także $w$ trakcie wykładów z etyki. Ich treść znamy dzięki notatkom Izydory Dąmbskiej, która przygotowała je do druku i udostępniła w 1971 roku. Zob. K. Twardowski, Wykłady z etyki. O sceptycyzmie etycznym, „Etyka” 1971, nr 9, s. 173-222.

18 Zob. R. Wiśniewski, Dyskusje metaetyczne w kręgu i wokót Szkoły Lwowsko-Warszawskiej, [w:] Polska filozofia analityczna. W kręgu Szkoły Lwowsko-Warszawskiej, materiały zebr. R. Jadczak, red. W. Tyburski, R. Wiśniewski, Torun 1999, s. 112. 
wziąć pod uwagę środowisko Szkoły Lwowsko-Warszawskiej, to analizy te są najbardziej dokładne i obszerne. W odróżnieniu od Twardowskiego, Tatarkiewicz zdał sobie sprawę, że zarówno relatywizm, jak i teza o bezwzględnym charakterze ocen etycznych są stanowiskami, które nie potrzebują argumentów. Cecha subiektywna może być względna lub bezwzględna, dlatego dowodu wymagają tezy subiektywizmu i obiektywizmu. Dalsze jego analizy prowadzą go jednak do twierdzenia o pewnej względności w odniesieniu do słuszności postępowania i reguł postępowania. Dobra są bezwzględne, ale reguły postępowania są względne i muszą uwzględniać okoliczności każdej konkretnej sytuacji, w której są stosowane. Stąd ograniczenia dla ogólnych reguł postępowania ${ }^{19}$.

Kwestia prawdziwości i fałszywości zdań o wartościach jest w rozprawie Tatarkiewicza nieobecna. Zdawał on sobie sprawę z tego, że zdania wartościujące mogą się wspierać tylko na innych zdaniach wartościujących. Stąd też nie ma potrzeby mówić o ich prawdziwości bądź fałszywości. Odnieść można wrażenie, że uwzględniając ten problem, Czeżowski potraktował wartości (dobro) jako transcendentalia. Transcendentalia to wyrażenia ponadkategorialne, które są treściowo i zakresowo zamienne. Stąd zamienność prawdy i dobra. Są to wyrażenia, które nadto odnoszą się do sposobów bycia (modi entis), co pozwala Czeżowskiemu uwzględnić zrelatywizowanie zdań wartościujących do konkretnej sytuacji i jednocześnie zachować bezwzględny charakterem dobra ${ }^{20}$.

Argumentacja przedstawiona powyżej nie jest wolna od obiekcji. Twardowski dostrzegał różnicę między prawdziwością zasad etycznych a ich uznawaniem za słuszne. Czynnikiem szczególnej wagi, nastręczającym poważnych trudności teoretycznych, jest tak zwane uczucie wartości oraz sumienie $^{21}$. Wprawdzie $w$ swojej argumentacji wspomniani filozofowie nie odwołują się do niego, jednakże odnieść można wrażenie, że intuicjonizm etyczny jest stanowiskiem bliskim dla każdego z nich, ponieważ przyjmują oni istnienie swoistej empirii etyczno-aksjologicznej, która w dociekaniach etycznych musi być uwzględniona. Rzecz jest istotna dla pozytywnych rozwiązań etycznych prezentowanych przez filozofów ze Szkoły Lwowsko-Warszawskiej, nie ma jednakże takiej wagi dla analiz krytycznych i zbicia argumentacji relatywistycznej.

Argumentacja za obiektywnością dobra zbudowana jest na dychotomii relatywizmu i obiektywizmu (absolutyzmu). Ale ujęcie takie można odwra-

\footnotetext{
19 W. Tatarkiewicz, O bezwzględności dobra, op. cit., s. 55-57.

${ }^{20}$ W kwestii analizy teorii transcendentaliów zob. D. Łukasiewicz, op. cit., s. 240-253.

${ }^{21}$ K. Twardowski, Etyka, op. cit., s. 62-63; R. Jadczak, Człowiek szukajacy etyki. Filozofia moralna Kazimierza Twardowskiego, Torun 1993, s. 27-28.
} 
cać: wykorzystując wszelkie zarzuty wobec stanowiska obiektywizmu, można argumentować za słusznością relatywizmu. Takie wątpliwości można na przykład skierować przeciwko tezie Czeżowskiego, że wartości przynależą do transcendentaliów, na co wskazywali Cezary Gorzka i Jacek Juliusz Jadacki. Wątpliwości te pozostają $\mathrm{w}$ wyraźnym związku $\mathrm{z}$ trudnościami $\mathrm{w}$ osiągnięciu spójności przez historycznie ukształtowane koncepcje transcendentaliów. Ma to swoje źródło w pojęciu „bytu”, które oznacza odmienne kategorie ontyczne. Różnice między kategoriami są na tyle duże, że można zapytać, czy w każdym wypadku odnoszone jest do nich to samo pojęcie "bytu"22. Otóż posługując się tego typu argumentami, można podważać samą koncepcję transcendentaliów, a co za tym idzie przynależność wartości do nich, a także ich obiektywizm.

Podkreślić trzeba kwestię, która jest osią całego sporu. Jak zauważała Maria Ossowska w polemice z Czeżowskim, nie sposób zbudować przejścia od tego, co ludzie uważają za dobre, do tego, czym dobro jest. Nieustannie mamy do czynienia jedynie z przeróżnymi naszymi poglądami na temat dobra. Gdyby wartości były postrzegalne powiedzmy tak, jak stół stojący przede mną, nie byłyby przedmiotem kontrowersji i sporów. Tak jednak nie jest, ponieważ nie dysponujemy kryteriami prawdziwości ocen; co więcej, wątpliwe jest nawet to, czy oceny mogą podlegać takim kryteriom jak prawda i fałsz ${ }^{23}$.

Wysiłek przywołanych $\mathrm{w}$ tym artykule filozofów zmierzał przede wszystkim do zbudowania poprawnej pod względem semantycznym argumentacji, która, z jednej strony, wymierzona by była przeciw relatywizmowi, z drugiej - dowodziła obiektywizmu dobra (wartości). Jak zauważa Józef Dębowski, komentując dociekania Twardowskiego, prowadzi to jednak do pewnego zapoznania perspektywy aksjologicznej w badaniach nad wartościami. Twardowski na przykład nie analizuje i nie odróżnia wartości autotelicznych i instrumentalnych ${ }^{24}$. Trzeba jednak od razu zaznaczyć, że przedstawione powyżej analizy przyczyniły się znacząco do uporządkowania i oczyszczenia błędów i nieporozumień narosłych wokół zagadnień etycznych i aksjologicznych. Miały one zadanie przygotowawcze przed pod-

22 C. Gorzka, Teoria wartości Tadeusza Czeżowskiego, „Ruch Filozoficzny” 1991, t. XLVIII, nr 1, s. 19-22; J.J. Jadacki, Kłopoty z kategoriami ontycznymi, czyli o (pewnych) pogladach filozoficznych Tadeusza Czeżowskiego, [w:] Polska filozofia analityczna..., op. cit., s. 75-88.

${ }^{23}$ M. Ossowska, Główne modele "systemów" etycznych, [w:] eadem, Podstawy nauki o moralności, Wrocław - Warszawa - Kraków 1994, s. 448.

${ }^{24}$ J. Dębowski, O bezwzględności prawdy, [w:] idem, Prawda i warunki jej możliwości, Olsztyn 2010, s. 70; J. Moroz, Dyskusja z relatywizmem prawdy w Szkole Lwowsko-Warszawskiej, Warszawa 2013, s. 76-87. 
jęciem wysiłku budowy etyki naukowej, co znalazło wyraz w refleksji filozoficznej nie tylko wspomnianych $\mathrm{w}$ artykule filozofów - Twardowskiego, Czeżowskiego czy Tatarkiewicza - ale także innych myślicieli z kręgu Szkoły Lwowsko-Warszawskiej.

\section{An Objective Nature of the Goodness in Lvov-Warsaw School}

\section{Summary}

The thesis that goodness and truth have objective and absolute nature is a solid feature of philosophers included to Lvov-Warsaw School. There are presented and analyzed critical arguments against thesis that goodness has relative and subjective nature formulated by Kazimierz Twardowski, Władysław Tatarkiewicz and Tadeusz Czeżowski. Apart from it there are described positive arguments for thesis the goodness is objective and absolute. In the end standpoinst of three philosophers are compared and there are shown correspondences and differences between them 